\title{
Assessment of Academic Achievements of Special Children
}

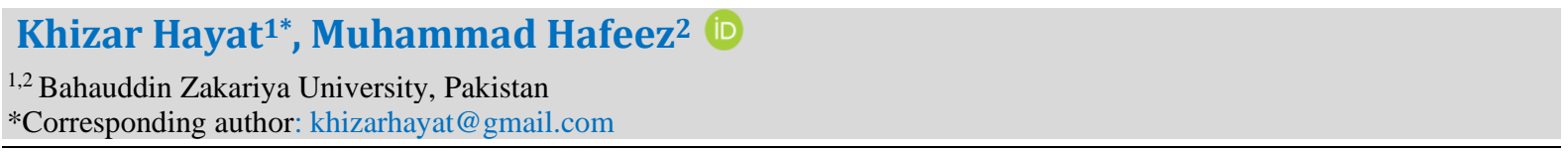

\begin{abstract}
Abstrak
Kecakapan hidup adalah kemampuan sosial dan psikologis yang sangat membantu dalam proses belajar dan mengembangkan masyarakat yang sehat dan sehat. Keterampilan ini memainkan peran kunci dalam prestasi akademik siswa. Prestasi akademik dan kecakapan hidup yang lebih baik memberikan jalan menuju prestasi akademik yang lebih baik. Pengembangan kecakapan hidup juga memegang peranan penting bagi pembangunan suatu masyarakat dan bangsa. Maka, mengetahui pentingnya kecakapan hidup maka dilakukan penelitian. Penelitian ini bertujuan untuk mengetahui kecakapan hidup siswa tunagrahita laki-laki dan perempuan (ii) menilai kecakapan hidup siswa tunagrahita perempuan dan laki-laki menurut pandangan gurunya (iii) menganalisis prestasi akademik siswa tunagrahita (iv) untuk menyelidiki dampak kecakapan hidup siswa tunagrahita terhadap prestasi akademik mereka. Total 20 siswa kelas 10 dipilih untuk studi saat ini. Peneliti menggunakan kuesioner untuk pengumpulan data. Kuesioner dibagikan kepada guru yang bersangkutan. Hasil belajar siswa kelas $X$ yang mengalami keterbelakangan mental dianalisis dengan menggunakan statistik deskriptif dan rumus persentase. Hasil penelitian menunjukkan bahwa siswa dengan keterbelakangan mental mencapai nilai akademik yang rendah. Dari 20 siswa, 4 siswa mendapat nilai 33\%, 7 siswa mendapat nilai 33-40\%, 5 siswa mendapat nilai 41-50\%, 4 siswa mendapat nilai 51-60\% dan tidak ada siswa yang mendapat nilai lebih dari 60\%. Rendahnya prestasi akademik siswa tunagrahita ini menunjukkan bahwa anak tunagrahita memerlukan perhatian dan upaya ekstra untuk mencapai prestasi akademik yang lebih baik. Jadi, disarankan agar anak asuh khusus harus dirawat dengan perhatian khusus.
\end{abstract}

Kata kunci: Kecakapan Hidup; Prestasi Akademik; Keterbelakangan mental; Siswa, Guru

\section{Abstract}

Life skills are the social and psychological abilities that are very helpful in the learning process and to develop a healthy and sound society. These skills play a key role in academic achievement of students. The better academic achievements and life skills provide a way to the better academic achievements. Life skills development also played an important role for the development of a society and nation. So, knowing the importance of life skills a research study was conducted. This study aims to investigate the life skills of male and female mentally retarted students (ii) to assess the life skills of female and male mentally retarded students as perceived by their teachers (iii) to analyze the academic achievements of the mentally retarded students (iv) to investigate the impact of the life skills of mentally retarded students on their academic achievement. The total 20 students of $10^{\text {th }}$ grade were selected for the current study. The researcher used questionnaire for data collection. The questionnaires were distributed among the concerned teachers. The academic achievements of $10^{\text {th }}$ grade students with mental retardation were analysed by using descriptive statistics and percentage formula. The results of the study showed that students with mental retardation achieved low academic scores. Out of 20 students, 4 students got 33\% marks, 7 students got 33-40\% marks, 5 students got $41-50 \%$ marks, 4 students got $51-60 \%$ marks and no students got more than $60 \%$ marks. This low academic achievements of students with mental retardation indicated that children with mental retardation needs special care and extra efforts to achieve better academic achievements. So, it is suggested that special care children must be cared with special attention.

Keywords: Life Skills; Academic Achievement; Mental Retardation; Students, Teachers

$\begin{array}{ll}\text { History: } & \text { Publisher: Undiksha Press } \\ \text { Received : August 19, } 2021 & \text { Licensed: This work is licensed under } \\ \text { Revised : August 23, } 2021 & \text { a Creative Commons Attribution 3.0 License } \\ \text { Accepted : September 20, } 2021 & \text { CC () () } \\ \text { Published : November 25, } 2021 & \text { SA }\end{array}$

\section{INTRODUCTION}

Learning is the necessary element for the life skills development (Ducasse \& Hill, 2019; Hafeez et al., 2020). Life skills are the capabilities for malleable and positive behaviour that allow people to deal efficiently with the difficulties and encounters of daily life. These capabilities facilitate the emotional, physical and mental well-being of persons (Phungsuk et al., 2017; Shin et al., 2018). The life skills are abilities that will support the learners to be 
fruitful in living a creative life (Cronin \& Allen, 2018). Educational and practicing life skills support learners to improve their individual and communal abilities such as self-confidence, sympathy, respect and assurance (Jacobs \& Wright, 2018). Life skills consist of three skills such as thinking, social and emotional skills (Shek et al., 2020). Thinking skills are the selfawareness interpersonal relationships Managing Feelings/emotions.

The social skills are the problem-solving and decision-making communication skills (Robison et al., 2020). These skills comprised of non-verbal and verbal communication, dynamic listening, and capability to express emotions and provide feedback. The capability to collaborate includes expressing respect for the people around us. The Emotional skills are the abilities to deal the stress creative thinking with empathy (Erickson et al., 2015). Life skills are the psycho-social capabilities which reinforce people themselves to allocate with demands of the life. Life skills growth is a normal development starts when a kid is born but it frequently requires involvement to boost up (Srikongphlee et al., 2018). The environment in which an individual grows, learns behaves provide the primary stages for life skills development (Adedokun, 2019). Life skills allow persons to recognize their weakness and strength for a stable behavior (Chiang et al., 2017).

There are ten essential life skills required for persons which come under general life skill category (Rokhayati \& Jayanti, 2018). They are empathy, self-awareness, critical thinking, problem solving, decision making, creative thinking, and effective communication, coping with stress, interpersonal relationship and coping with emotions (Álvarez-Bueno et al., 2017). These skills are interrelated to each other and works together for the development of individuals (Mohammadzadeh et al., 2019). The important emotional, social and cognitive life skills are shown in Figure 1.

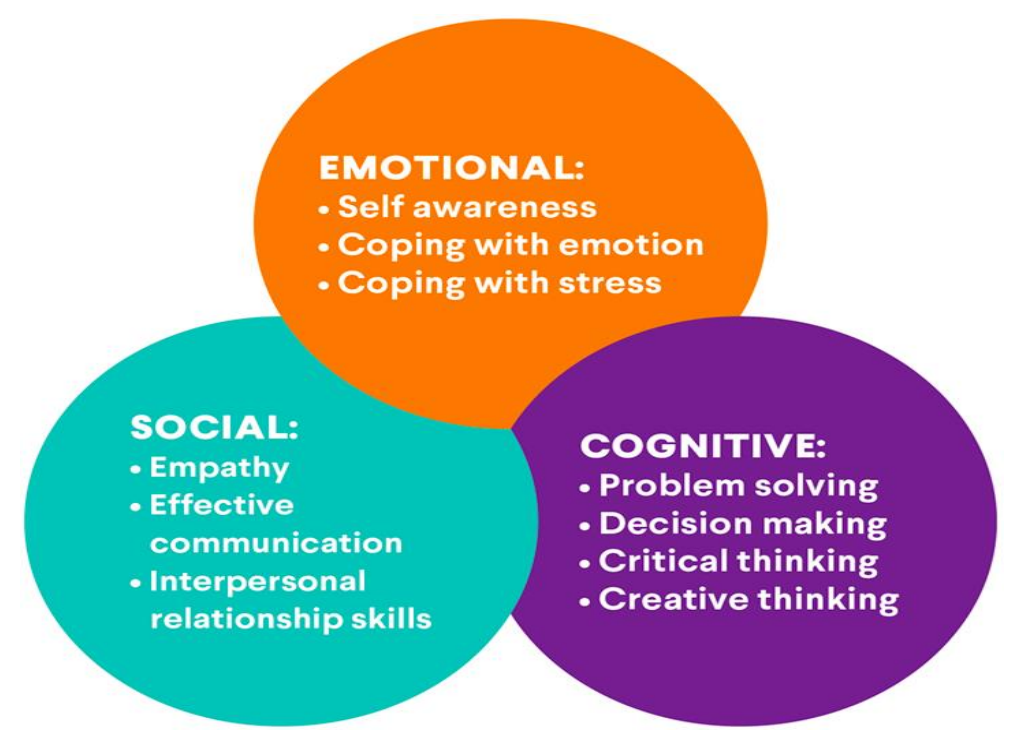

Figure 1. Emotional, Social and Cognitive Life Skills

Life skills comprised of interpersonal skills and psychosocial competencies that support individuals to solve problems, communicate effectively, think critically and creatively, empathize with others and build healthy relationships in a productive manner (Barken \& Armstrong, 2018). There are two types of life skills such as problem specific and generic life skills. Life skills are important elements for the proper development and growth of a child (Chen \& Yang, 2019). The life skills also play an imprtant role in critical thinking and academic achievements for the learners. The elements of life skills are the backbone for the social development and academic achievements for a child (Nasheeda et al., 2019). This study aims to investigate the life skills of male and female mentally retarted students, to 
assess the life skills of female and male mentally retarded students as perceived by their teachers, to analyze the academic achievements of the mentally retarded students, to investigate the impact of the life skills of mentally retarded students on their academic achievement.

\section{METHODS}

Causal comparative research methodology was used in current research study to evaluate the impacts of life skills on academic achievements of pupils with mentally challenged. The students were taken from the special education school situated in Dera Ghazi Khan, Punjab, Pakistan. The total size of the sample was 20 students with mental retardation studying in grade $10^{\text {th }}$ at the special education school situated in Dera Ghazi Khan, Punjab, Pakistan. The sample was selected by using random sampling technique. The semi structured close ended questionnaire was used as a tool for data gathering. The semi- structured questionnaire was designed to examine the life skills of pupils with mentally retarder who were studying in grade $10^{\text {th }}$ at special education school in Dera Ghazi Khan, Punjab, Pakistan. The questionnaire was distributed among the teachers of the students. There were 27 close ended statements were framed. The statements were coded on five-Likert scale comprising Strongly disagree (SD), Disagree (D), Undecided (UD), Agree (A) and Strongly Agree (SA). The statistical analysis of collected data was done by using SPSS-20 software package. The descriptive statistics tools were used to analyze and evaluate the collected data.

\section{RESULTS AND DISCUSSION}

\section{Results}

The results of questionnaire and descriptive statistics about the impacts of life skills on academic achievement of students with mental retardation are shown in Table 1 . The statement wise explanations of results are given in the following lines.

Table 1. Impact of Life Skills on the Academic Achievements of Students with Mental Retardation

\begin{tabular}{|c|c|c|c|c|c|c|c|}
\hline Statements & $\begin{array}{l}\text { SD } \\
(\%)\end{array}$ & $\begin{array}{l}\text { D } \\
(\%)\end{array}$ & $\begin{array}{l}\text { UD } \\
(\%)\end{array}$ & $\begin{array}{l}\mathrm{A} \\
(\%)\end{array}$ & $\begin{array}{l}\text { SA } \\
(\%)\end{array}$ & Mean & $\begin{array}{l}\text { St. } \\
\text { Dev. }\end{array}$ \\
\hline $\begin{array}{l}\text { Child shows creativity during the } \\
\text { classroom activities }\end{array}$ & 26.2 & 55.5 & 17.3 & 0.0 & 1.0 & 1.95 & 0.730 \\
\hline $\begin{array}{l}\text { Child accepts the challenge } \\
\text { enthusiastically }\end{array}$ & 20.0 & 59.4 & 19.4 & 0.0 & 1.1 & 2.03 & 0.705 \\
\hline $\begin{array}{l}\text { Child tries to present new ideas and } \\
\text { concepts }\end{array}$ & 16.8 & 44.3 & 37.3 & 0.5 & 1.2 & 2.27 & 0.776 \\
\hline Child asks questions about the set task & 13.8 & 55.7 & 28.2 & 1.8 & 0.7 & 2.21 & 0.710 \\
\hline $\begin{array}{l}\text { Child generates doubts by questioning } \\
\text { about unrelated things }\end{array}$ & 26.2 & 33.8 & 32.7 & 7.3 & 0.1 & 2.23 & 0.915 \\
\hline $\begin{array}{l}\text { Child attempts to help others during the } \\
\text { group activity }\end{array}$ & 29.3 & 32.3 & 32.1 & 5.1 & 1.2 & 2.17 & 0.946 \\
\hline $\begin{array}{l}\text { Child attempts to offer help for others in } \\
\text { special Tasks }\end{array}$ & 23.4 & 45.5 & 27.3 & 3.2 & 0.7 & 2.13 & 0.823 \\
\hline $\begin{array}{l}\text { Child tries to do a single activity in } \\
\text { different ways }\end{array}$ & 26.6 & 40.7 & 30.1 & 1.6 & 1.2 & 2.11 & 0.853 \\
\hline Child likes to think out of the box & 18.3 & 45.6 & 31.7 & 3.9 & 0.6 & 2.23 & 0.811 \\
\hline $\begin{array}{l}\text { Child tries to apply knowledge or skills in } \\
\text { new situations }\end{array}$ & 15.6 & 59.4 & 20.6 & 1.1 & 3.3 & 2.17 & 0.824 \\
\hline
\end{tabular}




\begin{tabular}{|c|c|c|c|c|c|c|c|}
\hline Statements & $\begin{array}{l}\text { SD } \\
(\%)\end{array}$ & $\begin{array}{l}\text { D } \\
(\%)\end{array}$ & $\begin{array}{l}\text { UD } \\
(\%)\end{array}$ & $\begin{array}{l}\text { A } \\
(\%)\end{array}$ & $\begin{array}{l}\text { SA } \\
(\%)\end{array}$ & Mean & $\begin{array}{l}\text { St. } \\
\text { Dev. }\end{array}$ \\
\hline $\begin{array}{l}\text { Child thinks about all the possible options } \\
\text { before a task }\end{array}$ & 18.9 & 44.4 & 35.0 & 0.6 & 1.1 & 2.21 & 0.789 \\
\hline $\begin{array}{l}\text { Child attempts to support a classmate } \\
\text { who is feeling low to cope up the given } \\
\text { work }\end{array}$ & 14.4 & 55.0 & 23.9 & 3.9 & 2.8 & 2.26 & 0.853 \\
\hline $\begin{array}{l}\text { Child feels relaxed in sharing his ideas } \\
\text { and concepts with others? }\end{array}$ & 18.8 & 39.0 & 37.8 & 4.4 & 0.0 & 2.28 & 0.819 \\
\hline $\begin{array}{l}\text { Child always enjoys to be respected and } \\
\text { appreciated }\end{array}$ & 19.5 & 51.0 & 23.2 & 5.2 & 1.1 & 2.17 & 0.838 \\
\hline $\begin{array}{l}\text { Child asks about how to right the errors } \\
\text { pointed out by the teacher in their tasks }\end{array}$ & 16.1 & 52.2 & 28.3 & 3.3 & 0.0 & 2.19 & 0.738 \\
\hline $\begin{array}{l}\text { Child keeps a relaxed level of eye contact } \\
\text { with tasks }\end{array}$ & 18.2 & 51.8 & 26.2 & 3.8 & 0.0 & 2.16 & 0.761 \\
\hline Child intrudes to tell their own opinions? & 17.2 & 45.6 & 35.0 & 2.2 & 0.0 & 2.22 & 0.752 \\
\hline $\begin{array}{l}\text { Child attempts to break rules and } \\
\text { principles setup for the tasks }\end{array}$ & 12.8 & 53.9 & 28.3 & 5.0 & 0.0 & 2.26 & 0.741 \\
\hline Child attempts to exhibit rude behavior & 18.3 & 55.0 & 21.7 & 3.3 & 1.7 & 2.15 & 0.815 \\
\hline $\begin{array}{l}\text { Child selects an activity according to his } \\
\text { capability during the group work }\end{array}$ & 18.3 & 43.3 & 31.1 & 5.0 & 2.2 & 2.29 & 0.901 \\
\hline $\begin{array}{l}\text { Child attempts to do the tasks again if } \\
\text { remained unsuccessful in first try }\end{array}$ & 7.7 & 51.2 & 36.6 & 2.3 & 2.3 & 2.41 & 0.759 \\
\hline $\begin{array}{l}\text { Child tries to improve the learning by } \\
\text { doing regular practice }\end{array}$ & 22.2 & 43.9 & 30.6 & 1.7 & 1.7 & 2.17 & 0.849 \\
\hline $\begin{array}{l}\text { Child attempts to take help of teacher in } \\
\text { difficult situations }\end{array}$ & 10.6 & 51.1 & 34.4 & 2.2 & 1.7 & 2.33 & 0.762 \\
\hline $\begin{array}{l}\text { Child attempts to get secluded when } \\
\text { under stress }\end{array}$ & 16.1 & 53.3 & 29.4 & 0 & 1.1 & 2.17 & 0.729 \\
\hline $\begin{array}{l}\text { Child attempts to do some healthy } \\
\text { activities }\end{array}$ & 22.8 & 36.7 & 35.0 & 4.4 & 1.1 & 2.24 & 0.895 \\
\hline $\begin{array}{l}\text { Child becomes argumentative during } \\
\text { discussions }\end{array}$ & 5.6 & 62.2 & 29.4 & 1.7 & 1.1 & 2.31 & 0.652 \\
\hline $\begin{array}{l}\text { Child demonstrations disrespect to the } \\
\text { discipline of the classroom }\end{array}$ & 14.5 & 43.8 & 36.0 & 5.1 & 0.6 & 2.33 & 0.805 \\
\hline
\end{tabular}

In respond to the statement that child shows creativity during the classroom activities, $82 \%$ teachers said that child does not show creativity during classroom activities. The mean value was 1.95 and standard deviation was 0.730 for this statement. In respond to the statement that child accepts the challenge enthusiastically, $80 \%$ teachers responded that child does not accept the challenge enthusiastically. The mean value for this statement was 2.03 and standard deviation was 0.705 . In respond to the statement that child tries to give new ideas and concepts, $61 \%$ teachers said that child does not try to give new ideas and concepts. The mean value for this statement was 2.27 and standard deviation was 0.776 . In respond to the statement that child asks questions about the set task, 70\% teachers responded that child does not ask questions about the set task. The mean score value for this statement was 2.21 and standard deviation was 0.710 .

In respond to the statement that child generates doubts by questioning about irrelevant things away from the task, $60 \%$ teachers responded that child does not generates doubts by questioning about irrelevant things. The mean value for this statement was 2.23 and standard 
deviation was 0.915 . In respond to the statement that child attempts to help others during group activity, $62 \%$ teachers responded that child does not try to help others during group activity. The mean value for this statement was 2.17 and standard deviation was 0.946 . In respond to the statement that child attempts to offer help for others in special tasks, $70 \%$ teachers responded that child does not attempts to offer help for others in special tasks. The mean value for this statement was 2.13 and standard deviation was 0.823 . In respond to the statement that child tries to do a single activity in different ways $68 \%$ teachers responded that child does not try to do a single activity in different ways. The mean value for this statement was 2.11 and standard deviation was 0.853 .

In respond to the statement that child likes to think out of the box, $64 \%$ instructors responded that child does not like to think out of the box. The mean value for this statement was 2.23 and standard deviation was 0.811 . In respond to the statement that child tries to apply knowledge or skills in new situation, $75 \%$ instructors responded that child does not try to apply knowledge or skills in new situation. The mean value for this statement was 2.17 and standard deviation was 0.824 . In respond to the statement that child thinks about all the possible options before a task, $64 \%$ teachers responded that child does not ponder about all the possible choices before a task. The mean value for this statement was 2.21 and standard deviation was 0.789 . In respond to the statement that child attempts to support a classmate who is feeling low to cope up the given work, $70 \%$ instructors responded that child does not attempt to support a classmate who is feeling low to cope up the given work. The mean value for this statement was 2.26 and standard deviation was 0.853 .

In respond to the statement that child feels relaxed in sharing his ideas and concepts with others, $58 \%$ teachers responded that child does not feel comfort in sharing his ideas with others. The mean value for this statement was 2.28 and standard deviation was 0.819 . In respond to the statement that child always enjoys to be respected and appreciated, $71 \%$ instructors responded that child does not enjoy to be respected and appreciated. The mean value for this statement was 2.17 and standard deviation was 0.838 . In respond to the statement that child asks about how to right the errors pointed out by the instructors in their work, $69 \%$ teachers responded that child does not ask about how to right the errors pointed out by the teachers in their work. The mean value for this statement was 2.19 and standard deviation was 0.738 . In respond to the statement that child keeps a comfortable level of eye contact with tasks, $70 \%$ teachers responded that child does not keep a relaxed level of eye contact with tasks. The mean value for this statement was 2.16 and standard deviation was 0.761. In respond to the statement child intrudes to tell their own opinions $63 \%$ teachers responded that child does not intrude to tell their own opinions. The mean value for this statement was 2.22 and standard deviation was 0.752 . In respond to the statement that child tries to break rules and principles setup for the task, 67\% teachers responded that child does not try to break rules and principles setup for the task. The mean value for this statement was 2.26 and standard deviation was 0.741 .

In respond to the statement that child tries to exhibit rude behavior, $74 \%$ teachers responded that child does not try to exhibit rude behavior. The mean value for this statement was 2.26 and standard deviation was 0.815 . In respond to the statement that child selects an activity according to his capability during the group work, $62 \%$ teachers said that child does not select an activity according to his capability during the group work. The mean value for this statement was 2.29 and standard deviation was 0.901. In respond to the statement that child attempts to do the task again if remained unsuccessful in first try, $60 \%$ teachers responded that child does not attempt to do the task again if remained unsuccessful in first try. The mean value for this statement was 2.40 and standard deviation was 0.759 . In respond to the statement that child tries to improve the learning by doing regular practice, $67 \%$ teachers responded that child does not try to improve the learning by doing regular practice. 
The mean value for this statement was 2.17 and standard deviation was 0.849 . In respond to the statement that child attempts to take help of teacher in difficult situations, $62 \%$ teachers responded that child does not attempt to take help of teacher in difficult situations. The mean value for this statement was 2.33 and standard deviation was 0.762 .

In respond to the statement that child attempts to get secluded when under stress, $70 \%$ teachers responded that child does not attempt to get secluded when under stress. The mean value for this statement was 2.17 and standard deviation was 0.729 . In respond to the statement that child attempts to do some healthy activities, 60 teachers responded that child do not attempt to do some healthy activities. The mean value for this statement was 2.24 and standard deviation was 0.895 . In respond to the statement that child becomes argumentative during discussions, 68\% instructors responded that child does not become argumentative during discussions. The mean value for this statement was 2.31 and standard deviation was 0.652. In respond to the statement that child demonstrations disrespect to the discipline of the classroom, $60 \%$ teachers said that child does not show disrespect to the discipline of the classroom. The mean value for this statement was 2.33 and standard deviation was 0.805 .

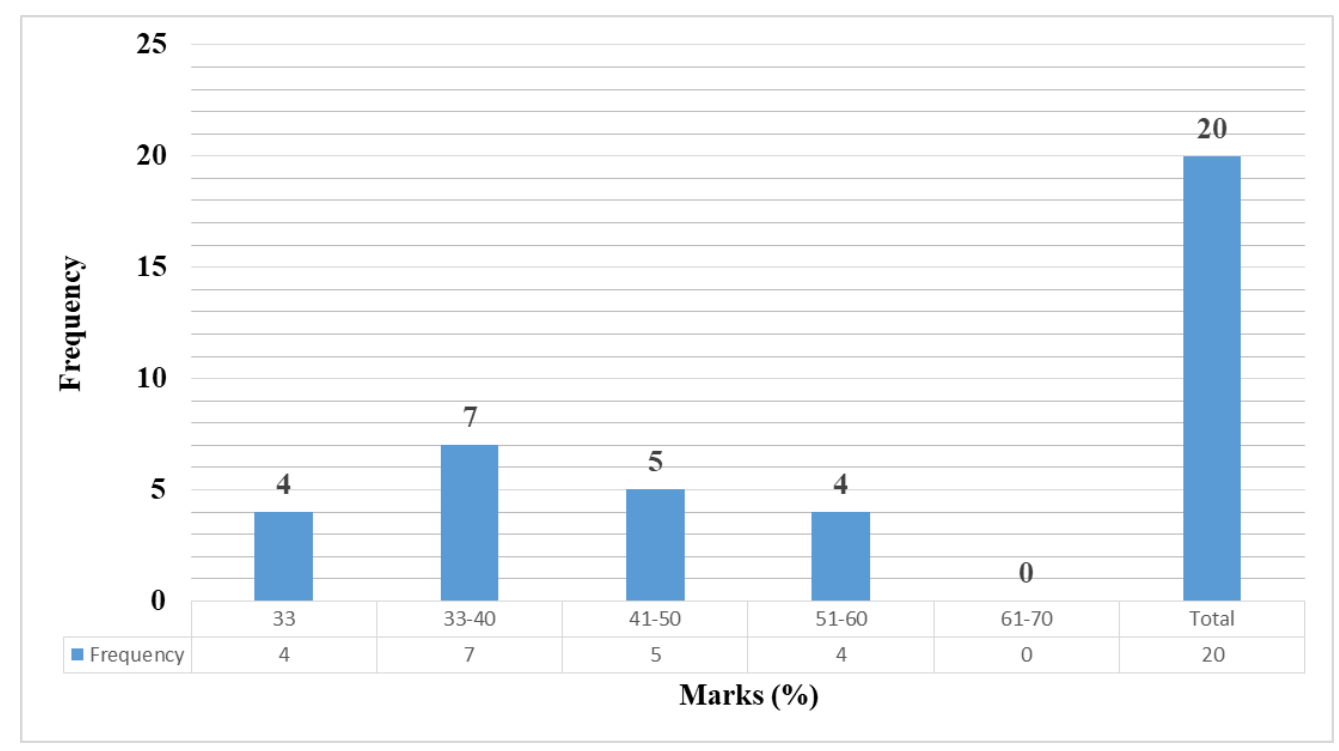

Figure 1. Graph between the Frequency and Percentage

Figure 1 displays the percentage and frequency of scores obtained by pupils. It is clear from table that 4 students obtained 33\% marks, 7 students obtained up to 33-40\% marks, 5 students obtained between $41-50 \%$ marks, 4 students obtained between 51-60\% marks and no students obtained more than $60 \%$ marks.

\section{Discussion}

\section{Mental Retardation}

The mental retardation is a term utilized when an individual has particular restrictions in mental working such as social skills and communicating. These restrictions will cause an individual to develop and learn more deliberately than a normal child (Coutinho et al., 2017). The individuals with any mental retardation take more time to speak, walk, learn and take care of their individual desires such as reaction or dressing (Putri et al., 2017). Mental retardation has been separated into four stages of severity largely bases on IQ numbers (i) for moderate mental retardation, IQ values range from 55/50 to 40/35 (ii) for mild mental retardation, IQ values range from 70 to $55 / 50$ (iii) for profound mental retardation, IQ values are below to 25/20 (iv) for severe mental retardation, IQ values range from 40/35 to 25/20. 
Mental retardation can be caused by any condition which impairs development of the brain (Baker, 2011). Several hundred reasons have been revealed, but about $1 / 3$ of the persons affected, the reason remains unidentified. The 3 major identified reasons of mental retardation are fetal Alcohol Syndrome, Down syndrome and Fragile X Syndrome (Verma et al., 2017).

\section{Life Skills}

The life skills are capabilities for malleable and positive practices that allow persons to deal efficiently with everyday life requirements and challenges (Suchyadi et al., 2018). The important life skills in individuals are (i) Problem solving (ii) Decision making (iii) Creative thinking (iv) Self-awareness (v) Self-awareness (vi) Coping with stress (vii) Interpersonal relationship skills (viii) Empathy (ix) Coping with emotions (x) Critical thinking (Hayden et al., 2015). The life skills education varies in its contents and purposes from nation to nation and from one place to another place. However, life skills education does not vary across cultures in three significant ways (Wurdinger \& Qureshi, 2015). Education is the main source for improving the life skills. Complementary life skills like creative and critical thinking, empathy, self-awareness and decision-making skills can be improved and developed by educational activities. The health promotion skills can be improved by teaching these skills for psychosocial competence (Ng et al., 2015).

\section{Life Skills Education Requirement in Schools}

The school is a suitable place for the implementation of life skills education as school is a valuable place where young child perform different social activities to improve their learning process (Behrani, 2016; Francis, 2019). The life skills teaching is extremely related to the daily requirements of leaners when it is taught in the schools with formulated curriculum (Amansoi \& Basseyii, 2017). Many research studies concluded that teaching of life skills in schools improves the efficacy and academic performance of the learners (Abualrob, 2019; Manjula, 2018). Life skills learning is a learning which prepares the learners with capabilities to develop the positive behavior according to the environment (Mayabi, 2015). Life skills are the important social and psychological capabilities that are very necessary for the development of a country and to achieve the better academic records. These Life skills are the important elements for the normal development of an individual (Bean et al., 2018). These life skills play a key role in the learning process and development (Alajmi, 2019). Educational and practicing life skills support learners to improve their indiviuals and social abilities such as self-confidence, respect, sympathy and assurance.

The mental retardation is a term utilized when an individual has particular restrictions in mental working such as social skills and communicating (Cronin \& Allen, 2018). These restrictions will cause an individual to develop and learn more deliberately than a normal child (Coutinho et al., 2017). The individuals with any mental retardation take more time to speak, walk, learn and take care of their individual desires such as reaction or dressing (Putri et al., 2017). Research was carried out to analyze the influence of life skills on academic achievements of pupils with mental retardation. The subject of the study was the mentally retarded students who are studying in special education school situated in Dera Ghazi Khan, Punjab, Pakistan. Total 20 students were selected for this study. In order to attain the objectives of research, a questionnaire was developed. There were 27 items in the questionnaire. The questionnaire was developed on five Likert-Scales to judge the impacts of life skills on academic achievements of pupils with mental retardation. The results of the questionnaire data showed that over all the participants responded negative which means that mental retardation is a great hurdle in academic achievement of the students. The results of the indicated that 4 students obtained 33\% marks, 7 students obtained up to $33-40 \%$ marks, 
05 students obtained between 41-50\% marks, 4 students obtained between 51-60\% marks and no students obtained more than $60 \%$ marks. The low academic achievements of the students indicated that mental retardation is a great hurdle in achieving the higher academic grades. These results were in according to the results of the studies (Dhingra \& Chauhan, 2017; Rogers, 2016; Saad, 2018). The consequences of the study also showed that the children with mental retardation need special attention and care so that they can also become skillful to cope with the society

\section{CONCLUSION}

Life skills are important social and psychological abilities that are necessary for indiviuals to cope with the society and to achieve the higher order thinking skills and academic achievements. These life skills are also important for the development of a country. A research was conducted to assess the impacts of life skills on academic achievements of the pupils with mental retardation. The $10^{\text {th }}$ grades students of a special school situated in Dera Ghazi Khan, Punjab, Pakistan was selected for the study. The results of the study indicated that life skills has a great impact on the academic achievements. Out of 20 students, 4 students obtained 33\% marks, 7 students obtained up to 33-40\% marks, 5 students obtained between $41-50 \%$ marks, 4 students obtained between 51-60\% marks and no students obtained more than $60 \%$ marks. The low academic achievements of the students indicated that mental retardation is a great hurdle in achieving the higher academic grades. The special children having less life skills require special attention. So, in the schools they must provide the facilities so that they can easily learn the necessary skills required for the daily life to cope with the challenges of the society.

\section{REFERENCES}

Abualrob, M. (2019). Determinants of Building 21st Century Skills in Palestinian Elementary Schools. Higher Education Studies Journal, 9(2), 108-116. https://doi.org/10.5539/hes.v9n2p108.

Adedokun, M. O. (2019). Life skills implication for community development. Journal of Emerging Trends in Educational Research and Policy Studies, 10(6), 367-373. https://hdl.handle.net/10520/EJC-1d03acf05b.

Alajmi, M. M. (2019). The impact of E-portfolio use on the development of professional standards and life skills of students: A case study. Entrepreneurship and Sustainability Issues, 6(4), 1714-1735. https://doi.org/10.9770/jesi.2019.6.4(12) .

Álvarez-Bueno, C., Pesce, C., Cavero-Redondo, I., Sánchez-López, M., Garrido-Miguel, M., \& Martínez-Vizcaíno, V. (2017). Academic achievement and physical activity: a meta-analysis. Pediatrics, 140(1). https://doi.org/10.1542/peds.2017-1498.

Amansoi, E. O. I., \& Basseyii, B. A. (2017). Assessment of Selected Science Process Skills Acquisition among Senior Secondary Schools Students in Calabar Education Zone of Cross River State, Nigeria. International Journal of Scientific Research in Education, 10(1), 119-126.

Baker, D. L. (2011). The politics of neurodiversity: Why public policy matters. Lynne Rienner Publishers.

Barken, R., \& Armstrong, P. (2018). Skills of workers in long-term residential care: Exploring complexities, challenges, and opportunities. Ageing International, 43(1), 110-122. https://doi.org/10.1007/s12126-017-9285-7.

Bean, C., Kramers, S., Forneris, T., \& Camiré, M. (2018). The implicit/explicit continuum of life skills development and transfer. Quest, 70(4), 456-470. https://doi.org/10.1080/00336297.2018.1451348. 
Behrani, P. (2016). Implementation aspects of life skills education program in central board of secondary education schools. International Education and Research Journal, 2(3), $68-71$.

Chen, C. H., \& Yang, Y. C. (2019). Revisiting the effects of project-based learning on students' academic achievement: A meta-analysis investigating moderators. Educational Research Review, 26, 71-81. https://doi.org/10.1016/j.edurev.2018.11.001.

Chiang, H. M., Ni, X., \& Lee, Y. S. (2017). Life skills training for middle and high school students with autism. Journal of Autism and Developmental Disorders, 47(4), 11131121. https://doi.org/10.1007/s10803-017-3028-1.

Coutinho, E., Jacobson, L., Pedersen, M. G., Benros, M. E., Nørgaard-Pedersen, B., Mortensen, P. B., ..., \& Vincent, A. (2017). CASPR2 autoantibodies are raised during pregnancy in mothers of children with mental retardation and disorders of psychological development but not autism. Journal of Neurology, Neurosurgery \& Psychiatry, 88(9), 718-721. https://doi.org/10.1136/jnnp-2016-315251.

Cronin, L. D., \& Allen, J. (2018). Examining the relationships among the coaching climate, life skills development and well-being in sport. International Journal of Sports Science \& Coaching, 13(6), 815-827. https://doi.org/10.1177\%2F174795411878794.

Dhingra, R., \& Chauhan, K. S. (2017). Assessment of life-skills of adolescents in relation to selected variables. International Journal of Scientific and Research Publications, 7(8), 201-212. http://ijsrp.org/.

Ducasse, A. M., \& Hill, K. (2019). Developing student feedback literacy using educational technology and the reflective feedback conversation. Practitioner Research in Higher Education, 12(1), 24-37. http://insight.cumbria.ac.uk/id/eprint/4574/.

Erickson, A. S. G., Noonan, P. M., Zheng, C., \& Brussow, J. A. (2015). The relationship between self-determination and academic achievement for adolescents with intellectual disabilities. Research in Developmental Disabilities, 36, 45-54. https://doi.org/10.1016/j.ridd.2014.09.008.

Francis, A. (2019). Teachers' and Students' Attitude on Effective Teaching of Life Skills Education in Secondary Schools. East African Scholars Journal of Education, Humanities, and Learning, 2(5). https://doi.org/10.36349/easjehl.2019.v02i05.004.

Hafeez, M., Kazmi, Q. A., Tahira, F., Hussain, M. Z., Ahmad, S., Yasmeen, A., \& Saqi, M. I. (2020). Impact of School Enrolment Size on Student's Achievements. Journal of Basic Education, 3(1), 17-21. https://doi.org/10.37728/ijobe.v3i1.302.

Hayden, L. A., Whitley, M. A., Cook, A. L., Dumais, A., Silva, M., \& Scherer, A. (2015). An exploration of life skill development through sport in three international high schools. Qualitative Research in Sport, Exercise and Health, 7(5), 759-775. https://doi.org/10.1080/2159676X.2015.1011217.

Jacobs, J. M., \& Wright, P. M. (2018). Transfer of life skills in sport-based youth development programs: A conceptual framework bridging learning to application. Quest, 70(1), 81-99. https://doi.org/10.1080/00336297.2017.1348304.

Manjula, M. (2018). Mental Health Promotion at Schools: Need, Challenges and Role of Teachers and Counsellors. Positive Schooling and Child Development, 249-268. https://doi.org/10.1007/978-981-13-0077-6_13.

Mayabi, M. J. (2015). Influence of School-Based Life Skills Education Programme on Students 'sexual Behaviour In Secondary Schools in Nairobi And Busia Counties Kenya. Kabarak University.

Mohammadzadeh, M., Awang, H., Ismail, S., \& Kadir Shahar, H. (2019). Improving emotional health and self-esteem of Malaysian adolescents living in orphanages through Life Skills Education program: A multi-centre randomized control trial. PloS 
One, 14(12). https://doi.org/10.1371/journal.pone.0226333.

Nasheeda, A., Abdullah, H. B., Krauss, S. E., \& Ahmed, N. B. (2019). A narrative systematic review of life skills education: effectiveness, research gaps and priorities. International Journal of Adolescence and Youth, 24(3), 362-379. https://doi.org/10.1080/02673843.2018.1479278.

Ng, Z. J., Huebner, S. E., \& Hills, K. J. (2015). Life satisfaction and academic performance in early adolescents: Evidence for reciprocal association. Journal of School Psychology, 53(6), 479-491. https://doi.org/10.1016/j.jsp.2015.09.004.

Phungsuk, R., Viriyavejakul, C., \& Ratanaolarn, T. (2017). Development of a problem-based learning model via a virtual learning environment. Kasetsart Journal of Social Sciences, 38(3), 297-306. https://doi.org/10.1016/j.kjss.2017.01.001.

Putri, N. D. A., Salim, A., \& Sunardi, S. (2017). the Effectiveness of the Use of Course Review Horay (Crh) Methods to Improve Numeracy Division Skill of Children with Mild Mental Retardation in Slb Negeri Surakarta, Indonesia Year 2016/2017. European Journal of Special Education Research, 1(1). https://doi.org/10.5281/zenodo.252956.

Robison, M. A., Mann, T. B., \& Ingvarsson, E. T. (2020). Life skills instruction for children with developmental disabilities. Journal of Applied Behavior Analysis, 53(1), 431448. https://doi.org/10.1002/jaba.602.

Rogers, H. B. (2016). The Mindful twenty-something: Life skills to handle stress... and everything else. New Harbinger Publications. https://doi.org/10.1080/0164212X.2017.1412277.

Rokhayati, R., \& Jayanti, M. D. (2018). Development of Teaching Materials that Contain Life Skills Values on Utama Junior High School Teacher, Depok. Hortatori: Jurnal Pendidikan Bahasa Dan Sastra Indonesia, 2(2), 87-91. https://doi.org/10.30998/jh.v2i2.68.

Saad, M. A. E. (2018). The Effectiveness of a Life Skills Training Based on the Response to Intervention Model on Improving Disruptive Behavior of Preschool Children. Online Submission, 7(2), 60-66. https://www.journals.lapub.co.uk/index.php/IJPES.

Shek, D. T., Lin, L., Ma, C. M., Yu, L., Leung, J. T., Wu, F. K., ..., \& Dou, D. (2020). Perceptions of adolescents, teachers and parents of life skills education and life skills in high school students in Hong Kong. Applied Research in Quality of Life, 1-14. https://doi.org/10.1007/s11482-020-09848-9.

Shin, J. C., Postiglione, G. A., \& Ho, K. C. (2018). Challenges for doctoral education in East Asia: a global and comparative perspective. Asia Pacific Education Review, 19(2), 141-155. https://doi.org/10.1007/s12564-018-9527-8.

Srikongphlee, V., Luvila, V., \& Kanato, M. (2018). Effectiveness of life skills training and promoting family environment to prevent youth substance abuse: a study in Khon Kaen, Thailand. International Journal, 15(50), 88-94. https://doi.org/10.21660/2018.50.

Suchyadi, Y., Ambarsari, Y., \& Sukmanasa, E. (2018). Analysis of Social Interaction of Mentally Retarded Children. JHSS (Journal of Humanities and Social Studies), 2(2), 17-21. https://journal.unpak.ac.id/index.php/jhss.

Verma, A., Srivastava, P., \& Kumar, P. (2017). Stress among parents having children with mental retardation: a gender perspective. Journal of Disability Management and Rehabilitation, 2(2), 68-72.

Wurdinger, S., \& Qureshi, M. (2015). Enhancing college students' life skills through projectbased learning. Innovative Higher Education, 40(3), 279-286. https://doi.org/10.1007/s10755-014-9314-3. 